\title{
A bicicleta e o ciclismo nas revistas Educação Physica e Sport Illustrado (1930 - 1940) - ordem urbana e novas relações com a natureza
}

\author{
Jean dos S. Mantovani ${ }^{\star}$ Carmen Lúcia Soares.
}

\section{Resumo}

Este trabalho, de cunho bibliográfico e documental, apoiou-se nos referenciais da história cultural e objetivou mapear e analisar representações (CHARTIER, 1991) que permearam os usos da bicicleta, assim como o surgimento do ciclismo em dois periódicos especializados em Educação Física e Esportes no Brasil, entre as décadas de 1930 e 1940: as revistas Educação Physica e Sport Illustrado. Este trabalho objetivou, ainda, tecer reflexões acerca de novas concepções e relações com a natureza que emergiram nas cidades brasileiras neste período, e que incrementaram os diversificados usos desse artefato da cultura material: a bicicleta. Em um contexto urbano, valores como a velocidade, impunham-se como signos do que era moderno, assim como certo deslumbramento pelas máquinas. A bicicleta compôs de modo bastante significativo, esse novo contexto. Assim, ciclismo e bicicleta expressaram o quão similar e o quão distinto foram essas novas relações com a natureza.

\section{Palavras-chave:}

Bicicleta, ciclismo, natureza.

\section{Introdução}

Em um período de revoluções industriais e científicas, um novo meio de transporte - a bicicleta movido a força de seu condutor, vai sofrendo ajustes e chega, ao final do século XIX, com uma configuração próxima da atual com relação ao seu conceito funcional; desde seu surgimento, as bicicletas simbolizavam modernidade e velocidade (GABORIAU, 1995) e muito rapidamente agregam outros usos para além de meio de transporte, alcançando assim os divertimentos e ganhando adeptos. Em sua diversidade de usos é que a bicicleta ganha espaço entre práticas corporais ao ar livre e, mais tarde, transforma-se em modalidade esportiva: o ciclismo. Nesse contexto é interessante pensar como que a bicicleta se relacionava com a urbanização e modernização do Brasil. Trabalhos como de MORAES (2014) e SCHETINO (2007), ajudam-nos a pensar as relações que as bicicletas estabeleceram em cidades brasileiras específicas.

Essa pesquisa objetivou mapear e analisar como as revistas Educação Physica e Sport Illustrado representaram a bicicleta e o ciclismo em suas páginas através de artigos, reportagens, publicidade e imagens tendo como delimitação temporal o período de circulação dos referidos periódicos (décadas de 1930 e 1940).

\section{Resultados e Discussão}

A bicicleta é um objeto da cultura material e seus usos apresentaram e apresentam possibilidades plurais. Com a imersão nas nossas fontes principais, podemos constatar que o discurso das Revistas no tocante a bicicleta e ao ciclismo eram diversos. No conjunto dos exemplares o nosso tema aparece de maneira latente através da publicidade, de fatos e curiosidades acerca do ciclismo como esporte, de preceitos ligados às benesses e males oriundos da prática do ciclismo, assim como questões higienistas ligadas ao corpo feminino.

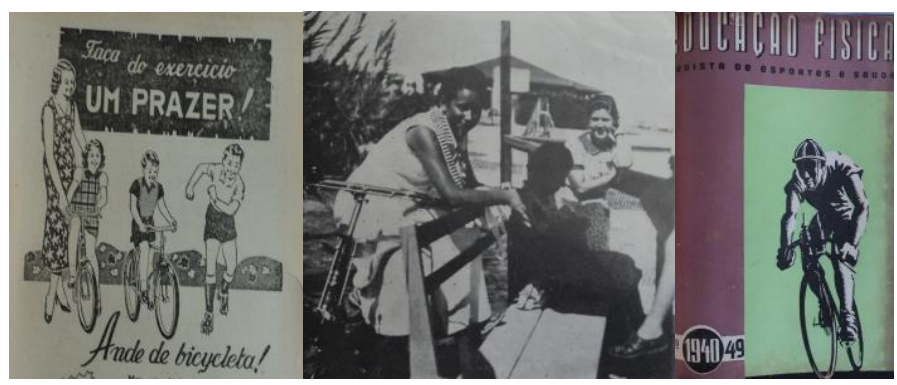

Figura 1. Rev. Educação Physica no 47, 1940, pg 63.

Figura 2. Rev. Sport Illustrado o 5, 1938, pg 7.

Figura 3. Rev. Educação Physica no 49, 1940, Capa.

\section{Conclusões}

As revistas trouxeram distintas representações acerca da bicicleta e do ciclismo no que se refere aos seus usos, seja como esporte e divertimento, seja no tom das orientações de seus discursos que ora enaltecem a virtude da bicicleta como exercício, ora ressaltam que os excessos poderiam afetar à saúde. Também se mostra dual o discurso quanto às mulheres. Se por um lado as revistas traziam muitas matérias tendo o corpo feminino como protagonista, estas sempre estavam ligadas a bicicleta enquanto divertimentos. Quando as revistas representavam o esporte ciclismo, este era sempre retratado pelos corpos masculinos.

$\mathrm{CNPq}-\mathrm{PIBIC}$

\section{Agradecimentos}

CHARTIER, Roger. O mundo como representação. Estud. av. São Paulo, v. 5, n. 11, p. 173-191, Apr. 1991

GABORIAU, Philippe. Le Tour de France et le vélo. Histoire sociale d'une épopée contemporaine. L'Harmattan, Paris, 1995.

MORAES, Ronaldo Dreissig de. O ciclismo nos clubes de Porto Alegre/RS: entre o passado e o presente. Dissertação (Mestrado) Universidade Federal do Rio Grande do Sul, UFRGS, Rio Grande do Sul, 2014. SCHETINO, André Maia. Pedalando na Modernidade - a bicicleta e o ciclismo no Rio de Janeiro e em Paris na transição dos séculos XIX-XX Dissertação (Mestrado em História Comparada) - Universidade Federal do Rio de Janeiro, IFCS, Rio de janeiro, 2007. 